\title{
Pemberdayaan Wanita Tani Melalui Pengembangan Keripik Singkong Di Sriten Pilangrejo, Nglipar, Gunungkidul
}

\author{
Indardi ${ }^{1}$ \\ ${ }^{1}$ Program Studi Agribisnis Universitas Muhammadiyah Yogyakarta, J. Brawijaya, Tamantirto, Kasihan, Bantul, D.I. Yogyakarta 55183 \\ Email: indardi@umy.ac.id \\ DOI: 10.18196/ppm.34.307
}

\begin{abstract}
Abstrak
Dusun Sriten merupakan salah satu dusun terluas yang ada di Desa Pilangrejo, Nglipar, Gunungkidul. Keseluruhan warga masyarakat bekerja di sektor pertanian, yakni usahatani tanaman pangan dan peternakan. Produksi tanaman pangan yang dihasilkan adalah padi, jagung, dan utamanya ubi kayu. Melimpahnya ubi kayu hanya dikeringkan menjadi gaplek, sedangkan harga gaplek sendiri Rp 1.500,-Rp 2.000,- $/ \mathrm{kg}$, serta belum terbukanya pikiran masyarakat petani Dusun Sriten untuk meningkatkan nilai tambah produk ubi kayu. Tujuan kegiatan yaitu membantu masyarakat Dusun Sriten untuk meningkatkan kualitas hidup melalui kegiatan penyuluhan dan pelatihan melalui pengolahan hasil pertanian guna untuk meningkatkan ekonomi pendapatan masyarakat. Konsep kegiatan meliputi pengorganisasian kelompok, memberikan penyuluhan dan pelatihan serta pendampingan kegiatan. Hasil kegiatan adalah terbentuknya Kelompok Wanita Tani Pengrajin Kripik Singkong, terlaksananya penyuluhan dan pelatihan pengolahan keripik singkong dan terakhir terbukanya jejaring pemasaran produk (7 outlet/took). Di akhir acara pelatihan pembuatan keripik singkong dilakukan serah terima alat perajang otomatis, spinner, bumbu aneka rasa, toples pencampur bumbu kepada KWT. Kesimpulan kegiatan sosialisasi terkait dengan adanya penyuluhan dan pelatihan disambut baik oleh tokoh masyarakat dan ibu-ibu Dusun Sriten. Kegiatan penyuluhan dengan materi 1) motivasi pentingnya usaha berkelompok, 2) menajemen kelompok, 3) jejaring pemasaran dalam pemberdayaan masyarakat, 4) penyuluhan pembuatan keripik singkong aneka rasa. Penyuluhan berjalan lancar dan efektif terjadi peningkatan pemahaman terhadap materi penyuluhan secara siknifikan. Kegiatan pelatihan pembuatan keripik singkong berjalan dengan lancar dan ada keyakinan pada diri ibu-ibu bisa memproduksi secara mandiri. Dalam kegiatan pembukaan jejaring pemasaran masih relatif terbatas karena terkait kondisi topografi wilayah Dusun Sriten yang terjal dan jauh dari akses jalan raya dan keterbatasan kepemilikan kendaraan bermotor.
\end{abstract}

Kata Kunci: Pemberdayaan, Kelompok Wanita Tani, Keripik Singkong

\section{Pendahuluan}

Pemberdayaan masyarakat merupakan salah satu program pemerintahan desa dalam memanfaatkan semua sumber daya yang ada agar dapat berkembang serta dapat membantu proses kemajuan desa. Menurut (Noor, 2011), upaya untuk memberdayakan masyarakat dapat dikaji menjadi 3 aspek: 1) Enabling yaitu menciptakan suasana yang memungkinkan potensi masyarakat dapat berkembang., 2) Empowering yaitu memperkuat potensi yang dimiliki masyarakat melalui langkah-langkah nyata yang menyangkut penyediaan berbagai input dan pembukaan dalam berbagai peluang yang akan membuat masyarakat semakin berdaya, 3) Protecting yaitu melindungi dan membela kepentingan masyarakat lemah ini merupakan unsur terpenting dalam pemberdayaan masyarakat. Untuk itu diperlukan analisis pemenuhan kebutuhan dan needs assessment yang tepat agar kegiatan pemberdayaan masyarakat dapat berjalan secara optimal. Langkah yang dapat ditempuh yaitu dengan cara mendorong terjadinya partisipasi masyarakat sasaran, antara lain melalui: identifikasi potensi, analisis kebutuhan, rencana kerja bersama, serta monitoring dan evaluasi yang berkelanjutan (Karsidi, 2007).

Gunungkidul merupakan salah satu kabupaten yang berada di Provinsi DIY tercatat memiliki 768.523 jiwa pada tahun 2019 dengan luas wilayah mencapai $1.485,36 \mathrm{~km}^{2}$ atau 46,63\% dari luasan Provinsi DIY (Badan Pusat Statistik, 2020). Kabupaten Gunungkidul 
memiliki topografi yang unik jika dibandingkan dengan kabupaten lainnya di Provinsi DIY sehingga untuk sektor pertanian lebih cocok ditanami tanaman palawija seperti umbi-umbian. Salah satu yang menjadi unggulan di Kabupaten Gunungkidul adalah ubi kayu yang merupakan bahan dasar pembuatan gaplek.

Tabel 1. Luas panen, Rata-rata Produksi dan Total Produksi Kabupaten Gunungkidul tahun 2016

\begin{tabular}{|c|c|c|c|c|}
\hline No & $\begin{array}{c}\text { Jenis } \\
\text { Tanaman }\end{array}$ & $\begin{array}{l}\text { Luas Panen } \\
\text { (Ha) }\end{array}$ & $\begin{array}{l}\text { Produksi } \\
\text { (Ton) }\end{array}$ & Rata-rata Produksi (Ton/ha) \\
\hline 1 & Padi sawah & $15.204,0$ & $92.538,0$ & 6,09 \\
\hline 2 & Jagung & $54.632,0$ & $238.322,0$ & 4,36 \\
\hline 3 & Ubi Kayu & $48.244,0$ & $1.029 .196,0$ & 21,33 \\
\hline 4 & Ubi Jalar & 46,0 & 503,0 & 10,93 \\
\hline 5 & Kacang Tanah & $61.937,0$ & $66.545,0$ & 1,07 \\
\hline 6 & Kedelai & $9.170,0$ & $11.079,0$ & 1,21 \\
\hline
\end{tabular}

Sumber: Analisis data (Dinas Pertanian DIY, 2016)

Berdasarkan tabel 1, diketahui bahwa ubi kayu memiliki rata-rata produksi terbesar diantara jenis tanaman lainnya yaitu sebesar 21,33 ton/ha, sementara produksi terkecil adalah kacang tanah yang hanya menghasilkan 1,07 ton/ha. Melimpahnya hasil panen ubi kayu juga dirasakan oleh masyarakat Dusun Sriten, membuat peluang usaha yang prospektif bagi masyarakat jika diolah dan dipasarkan dengan baik.

Kegiatan masyarakat Dusun Sriten yang hanya mengolah ubi kayu menjadi gaplek membuat tidak optimalnya pemanfaatan peluang tersebut, sehingga hal ini berdampak bagi pendapatan rumah tangga dan perekonomian masyarakat yang relative belum baik bagi masyarakat Dusun Sriten. Rata-rata harga yang ditawarkan masyarakat dalam menjual hasil olahan ubi kayu berupa gaplek hanya Rp. 1.500 hingga Rp 2.000 per kilogramnya. Dengan harga jual yang rendah menyebabkan masyarakat Dusun Sriten kesulitan dalam meningkatkan pendapatan rumah tangganya. Minimnya pengetahuan masyarakat mengenai nilai tambah produk olahan ubi kayu, kurangnya kesadaran pentingnya usaha secara berkelompok dan kurangnya jaringan pasar yang dimiliki masyarakat. Di sisi lain ada potensi pasar seperti objek wisata yang ada di Dusun Sriten itu sendiri dan potensi objek wisata lainnya yang tersebar diberbagai wilayah di Gunungkidul khususnya sekitar Desa Pilangrejo membuat masyarakat Dusun Sriten memiliki potensi yang sangat besar untuk melakukan peningkatan perekonomiannya.

Dengan berbagai situasi dan potensi di Dusun Sriten tersebut, maka dibutuhkan campur tangan pihak luar untuk memberikan solusi dengan memberikan penyuluhan dalam memotivasi kaum perempuan akan pentingnya usaha bersama melalui kelompok wanita tani, penguatan kelompok, sekaligus memberikan pelatihan untuk peningkatan nilai tambah produk pertanian dengan pembuatan keripik singkong aneka rasa sekaligus pendampingan dalam membuka jejaring pasar di Dusun Sriten, Pilangrejo, Nglipar, Kabupaten Gunungkidul. Itulah pentingnya dilakukan kegiatan Pengabdian Masyarakat program KKN PPM di dusun tersebut.

Berdasarkan solusi permasalahan dari kegiatan pengabdian program KKN-PPM tersebut, jenis luaran yang dihasilkan mencakup terjadinya peningkatan pengetahuan tentang pentingnya usaha secara berkelompok, pengetahuan pentingnya memiliki motivasi yang kuat agar berhasil dalam berusaha, pentingnya pengetahuan tentang manajemen kelompok dalam berusaha. Selanjutnya masyarakat wanita tani memiliki ketrampilan yang lebih baik dalam pembuatan keripik singkong aneka rasa, bisa menggunakan teknologi alat perajang ubi kayu, bisa menggunakan teknologi pengering keripik singkong, mampu membuka jaringan pasar keripik singkong, mampu bertahan tetap berproduksi pasca pelatihan. Berdasarkan pengalaman pengabdian melalui dengan program yang sama, yakni ketika melakukan 
pengabdian program KKN-PPM di Dusun Semuluh Lor, Desa Ngeposari, Semanu, Gunungkidul memberikan hasil bahwa ibu-ibu mengikuti kegiatan dengan sungguh-sungguh dari awal hingga akhir. Ibu-ibu memiliki semangat yang tinggi untuk melakukan pelatihan pembuatan keripik singkong. Ada keyakinan pada diri ibu-ibu KWT untuk mencoba secara mandiri berusaha keripik singkong (Indardi, 2019). Disamping itu juga telah mampu membuka jaringan pasar ke toko-toko kelontong yang ada di Dusun Semuluh Lor, toko-toko yang ada di sekitar dusun Semuluh Lor, outlet-outlet di tempat wisata pantai Gunungkidul dan sebuah swalayan di Kecamatan Semanu.

\section{Metode Pelaksanaan}

Program peningkatan ekonomi dengan perbaikan nilai tambah produk olahan singkong dilaksanakan mengarah pada pencapain output yang telah ditetapkan yaitu;

1. Terbentuknya kelompok pengrajin keripik singkong yang didahului sosialisasi dan penyuluhan

2. Adanya kegiatan ekonomi melalui pembuatan keripik singkong yang dipasarkan dilingkungan pedesaan dan obyek wisata

3. Adanya peningkatan ekonomi masyarakat Dusun Sriten yang berasal dari produk olahan keripik singkong.

Konsep kegiatan digambarkan melalui skema berikut:

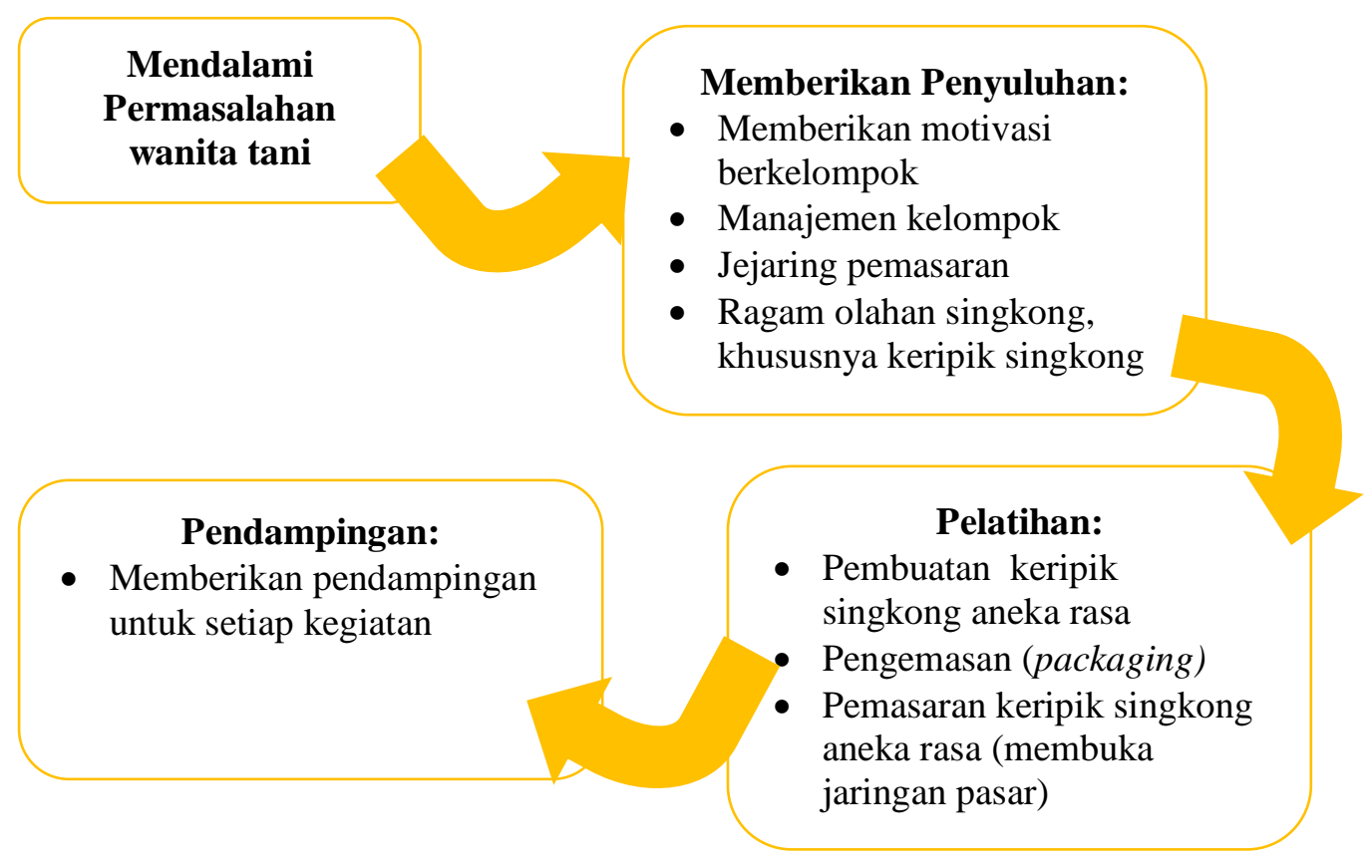

Gambar 1. Skema KKN-PPM Pelatihan Pengolahan Singkong

Dari konsep kegiatan diatas dalam pengabdian masyarakat sudah memenuhi aspekaspek untuk memberdayakan masyarakat dapat dikaji menjadi 3 yaitu: 1) Enabling yaitu menciptakan suasana yang memungkinkan potensi masyarakat dapat berkembang, 2) Empowering yaitu memperkuat potensi yang dimiliki masyarakat melalui langkah-langkah nyata yang membuka berbagai peluang yang akan membuat masyarakat semakin berdaya, 3) Protecting yaitu melindungi dan membela kepentingan masyarakat lemah ini merupakan unsur terpenting dalam pemberdayaan masyarakat (Noor, 2011). 
Ada beberapa kegiatan yang dilakukan selama pelaksanaan pengabdian KKN-PPM berlangsung, diantaranya adalah:

1. Sosialisasi dan Penyuluhan Pembuatan Keripik Singkong

Kegiatan pengabdian KKN-PPM UMY 2020 di Dusun Sriten, Desa Pilangrejo, Nglipar memiliki program kerja utama pemberdayaan wanita tani untuk meningkatkan perekonomian masyarakat dengan perbaikan nilai tambah produk pertanian olahan singkong. Singkong merupakan salah satu hasil pertanian unggulan di Dusun Sriten, Pilangrejo, Nglipar, Gunung Kidul. Sosialisasi yang dilakukan terdiri dari beberapa tahap. Setelah melalui 2 kali observasi bersama mahasiswa dan diyakini pentingnya melakukan kegiatan pemberdayaan kelompok wanita tani melalui perbaikan nilai tambah produk olahan singkong di Dusun Sriten ini, sosialisasi pertama dilaksanakan bersamaan kegiatan penerjunan KKN, tepatnya setelah upacara penerjunan di desa, dilanjutkan sosialisasi di kediaman Kepala Pedukuhan Sriten pada Selasa, 7 Januari 2020. Sosialisasi pertama ini dihadiri oleh pak dukuh, bu dukuh, ibu RT dari 4 RT yang ada di Dusun Sriten dan ketua kelompok tani. Pada pertemuan ini disampaikan akan adanya kegiatan penyuluhan dan pelatihan pembuatan keripik singkong aneka rasa, dan disambut antusias oleh semua tokoh masyarakat yang hadir. Pada tahap pertama sosialisasi ini juga dibahas tentang materi penyuluhannya. Apakah hanya penyuluhan tentang cara pembuatan keripik singkong aneka rasa atau ada hal-hal lain yang juga diperlukan ibu-ibu masyarakat Dusun Sriten. Pertemuan tahap pertama ini menggali berbagai masukan, termasuk juga tanggal berapa akan dilakukan kegiatan penyuluhan dan pelatihan pembuatan kripik singkong. Pada sosialisasi ini kendala yang dihadapi terutama terkait waktu. Kebetulan bulan Februari akan ada lomba desa, dan di bulan januari adalah hari persiapan lomba, dan hampir setiap hari ibu-ibunya ada pertemuan, koordinasi, latihan di balai desa. Alhamdulillah ada kesepakatan ada sebagian ibu ke balai desa dan ada sebagian ibu yang nantinya datang pada kegiatan penyuluhan di rumah pak Dukuh Sriten. Pada hari berikutnya, Rabo 8 Januari 2020 dilakukan sosialisasi kedua untuk menyampaikan kegiatan penyuluhan dengan sejumlah materi yang telah didiskusikan di sosialisasi pertama. Akhirnya disepakati untuk kegiatan penyuluhannya direncanakan dilaksanakan pada Hari Selasa 14 Januari 2020 dan materi penyuluhannya meliputi motivasi "Pentingnya Usaha Berkelompok, Manajemen Kelompok, Jejaring Pemasaran dalam Pemberdayaan Masyarakat dan Penyuluhan Pembuatan Keripik Singkong Aneka Rasa”.

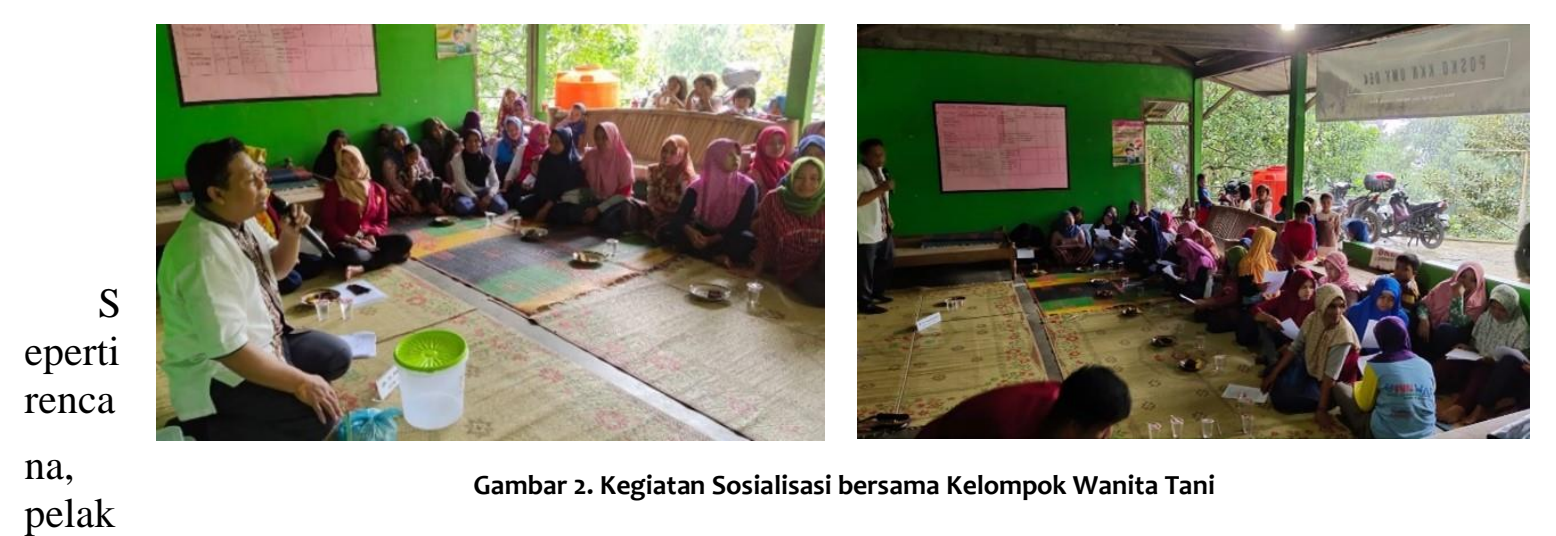

sanaan penyuluhan kepada ibu-ibu warga Dusun Sriten dimulai pukul 09.00 wib dan selesai sekitar pukul 14.00 wib, dengan materi seperti yang telah disepakati pada sosialisasi tahap kedua, yakni penyuluhan untuk memotivasi ibu-ibu untuk usaha secara berkelompok, pengelolaan kelompok, pentingnya jejaring dalam pemasaran dan penyuluhan pembuatan keripik singkong aneka rasa. Pelaksanaan penyuluhan di awali dengan pemberian pre test 
berkenaan dengan materi yang akan disampaikan dan setelah penyuluhan diberikan post test terkait materi yang disampaikan. Hal ini dilakukan untuk mengetahui seberapa paham peserta tentang usaha secara berkelompok dan terkait pembuatan olahan keripik singkong, dengan melakukan pembagian kuesioner yang wajib diisi oleh para peserta Sosialisasi yang telah disiapkan oleh pembicara utama yaitu Dr. Ir. Indardi M.Si. (NIDN 0513106501). Rata-rata perolehan skor pemahaman materi pre test sebesar 42 persen dan perolehan skor pemahaman materi post test sebesar 85 persen. Ada peningkatan pemahaman yang sangat signifikan, ada peningkatan pemahaman terkait materi penyuluhan lebih dari 100 persen. Penyuluhan pada tanggal 14 Januari 2020 dihadiri ibu-ibu warga Dusun Sriten sebanyak 15 orang. Setelah dilakukan post test dilakukan diskusi. Hasil diskusi setelah penyuluhan disepakati dibentuk kelompok wanita tani (KWT) Dusun Sriten. KWT Dusun Sriten yang baru dibentuk ini menggunakan kelompok ibu-ibu yang sudah ada sebelumnya yang memang sudah lama tidak aktif, tidak ada kegiatan sama sekali. Dengan demikian KWT Pengrajin Keripik Singkong, merupakan pengaktifan kembali kelompok ibu-ibu yang sudah lama tidak berjalan, dengan struktur organisasi ketua, sekretaris, bendahara dan koordinator wilayah dari masing-masing RT (ada 4 RT). Hal yang menggembirakan adalah semangat, antusiasme dan kesungguhan ibu-ibu mengikuti penyuluhan dari awal hingga akhir. Yang lebih menggembirakan lagi adalah, ketika diingatkan bahwa pelaksanaan pelatihan akan dilaksanakan pada Hari Sabtu Tanggal 25 Januari mereka akan hadir lebih banyak lagi, akan mengutamakan pelatihan pembuatan keripik singkong, dari berbagai kesibukan lainnya.

2. Pelatihan Pembuatan Keripik Singkong

Kegiatan berikutnya setelah sosialisasi dan penyuluhan dari pengabdian KKN PPM UMY adalah melakukan pelatihan pembuatan keripik singkong aneka rasa yang didampingi oleh Dr. Ir. Indardi M.Si. (NIDN 0513106501). Pelaksanaan pelatihan pembuatan keripik singkong juga dilaksanakan di rumah Kepala Padukuhan Sriten pada Sabtu, 25 Januari 2020 dengan jumlah peserta 32 orang.

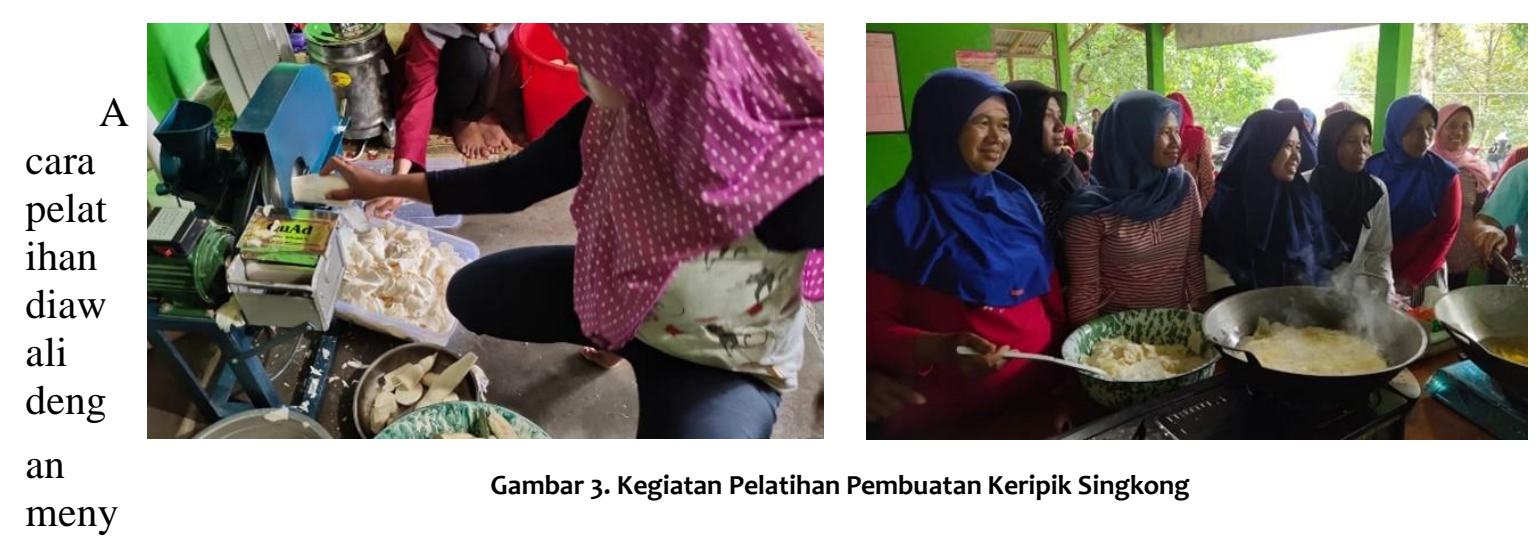

ampaikan kembali sekaligus untuk mengingatkan kembali tentang cara pembuatan keripik singkong secara singkat, yang sebelumnya secara rinci dan detail sudah disampaikan di acara penyuluhan pada tanggal 14 Januari 2020. Praktek pembuatan keripik singkong aneka rasa dipandu oleh pendamping dan dibantu oleh mahasiswa KKN kelompok 054 Dusun Sriten. Praktek pembuatan keripik singkong dimulai dari menguliti singkong, mencuci singkong sampai bersih dan melakukan perajangan dengan alat perajang otomatis. Rajangan singkong di rendam dalam kapur sirih dengan waktu yang berbeda-beda (10 menit, 20 menit, 30 menit dan 40 menit) sesuai dengan jumlah kelompok/RT (4 RT). Perbedaan waktu perendaman singkong yang sudah dirajang ke dalam air kapur sirih, dimaksudkan untuk melihat tingkat kerenyahan. Setelah itu dicuci bersih dan ditiriskan, kemudian dicampur dengan bumbu originalnya, yakni garam dan bawang putih yang dihaluskan. Selanjutnya singkong yang sudah dirajang tipis dengan bumbu original tersebut digoreng dengan minyak yang cukup 
sampai berwarna kekuningan (sudah matang). Keripik singkong tersebut selanjutnya ditiriskan dengan menggunakan "spinner". Setelah benar-benar kering dari minyak, dikeluarkan dari "spinner", dicampur dengan bumbu aneka rasa. Agar lebih cepat dan merata bumbunya pada semua sisi dari keripik singkong, di campur dengan menggunakan toples plastik yang ditutup rapat dan dikocok. Pengocokan dilakukan secara perlahan agar keripik singkong tetap utuh dan tidak hancur. Bumbu rasa terdiri dari bumbu rasa jagung bakar, ayam bakar, sapi panggang, sambalado, baberque, keju, pedas manis disamping juga ada rasa originalnya. Setelah dingin dimasukkan dalam plastik kemasan berlogo yang sudah disiapkan. Selanjutnya Diakhir acara sosialisasi dan pelatihan pembuatan keripik singkong dilakukan serah terima alat meliputi perajang singkong automatic, spiner, toples plastik pencampur bumbu (bumbu aneka rasa). Serah terima tersebut dilakukan oleh Dosen Pendamping Lapangan (yang menyerahkan) dan Kepala Dukuh Sriten (yang menerima), yang selanjutnya diberikan kepada Ketua Kelompok Wanita Tani Dukuh Sriten. Dosen juga memberikan bantuan modal pembuatan keripik singkong untuk produksi selanjutnya sebesar Rp 500.000,-.

3. Pembukaan Jaringan Pemasaran Keripik Singkong

Keripik singkong kemasan yang diproduksi oleh KWT Dusun Sriten diberi nama keripik singkong "Kripsten", yang artinya keripik singkong Sriten. Setelah diproduksi melalui pelatihan dan produksi mandiri (setelah pelatihan), selanjutnya dipasarkan. Membuka jejaring pasar dalam menjual produk keripik singkong aneka rasa dengan nama "Kripsten" dilakukan oleh ibu-ibu anggota KWT Dusun Sriten yang di damping oleh 9 mahasiswa KKN kelompok 054. Dalam kegiatan membuka pasar ini, seorang ibu didampingi oleh 3 orang mahasiswa menawarkan ke outlet, warung kelontong, toko ataupun swalayan yang ada di wilayah Nglipar, yang lokasinya baik pada tingkat kecamatan, desa ataupun Dusun Sriten itu sendiri.

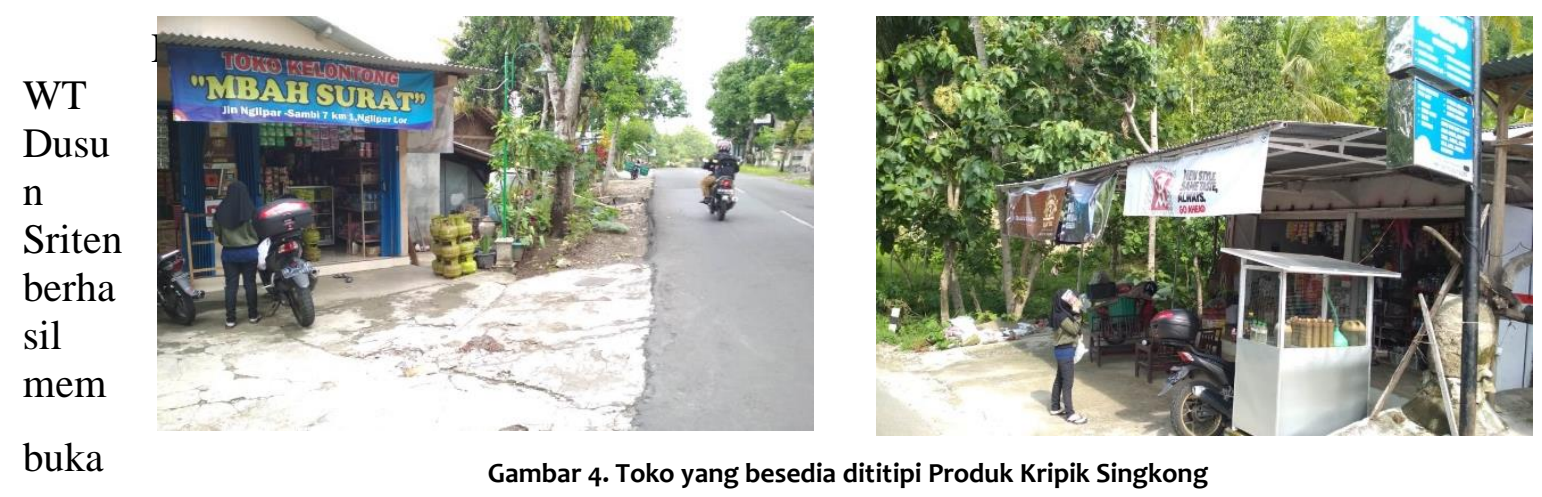

pasar

Gambar 4. Toko yang besedia dititipi Produk Kripik Singkong

untuk penitipan hasil keripik singkong aneka rasa "Kripsten" tersebut di 7 tempat (outlet, warung kelontong, toko, swalayan) di wilayah administrative Kecamatan Nglipar. Ada 2 tempat (toko dan Swalayan) di sekitar kota Kecamatan Nglipar, ada 4 tempat (outlet, warung kelontong, toko dan swalayan) di sekitar Kantor Desa Pilangrejo dan 1 outlet di Embung Batara Dusun Sriten. Kebetulan Dusun Sriten ini memiliki tempat wisata dengan nama Wisata Embung Batara. Posisinya terletak di puncak bukit yang ada di Dusun Sriten, biasa disebut Embung tertinggi di Gunung kidul. Sampai saat ini pemasaran produk keripik singkong "Kripsten" masih berjalan dan sudah rutin dilakukan oleh KWT Dusun Nglipar. Diharapkan produksi keripik singkong terus berjalan, dan pemasaran keripik singkong "Kripsten" produksi ibu-ibu anggota KWT Sriten ini dapat terus berkelanjutan, bahkan berkembang. Dalam kegiatan pembukaan jejaring pemasaran masih relatif terbatas karena terkait kondisi topografi wilayah Dusun Sriten yang terjal dan jauh dari akses jalan raya dan keterbatasan kepemilikan kendaraan bermotor. Sampai saat ini baru ada 7 tempat (outlet, warung kelontong, toko dan Swalayan) yang bersedia dititipi produk Keripik Singkong Aneka Rasa di 
wilayah Dusun, Desa dan Kecamatan Nglipar.

\section{Simpulan}

Pengabdian masyarakat Program KKN-PPM UMY di Dusun Sriten Desa Pilangrejo Kecamatan Nglipar telah terlaksana dengan lancar. Kegiatan Sosialisasi terkait dengan adanya penyuluhan dan pelatihan disambut dengan baik oleh tokoh masyarakat dan ibu-ibu Dusun Sriten. Kegiatan penyuluhan dengan materi 1) motivasi pentingnya usaha berkelompok, 2) menajemen kelompok, 3) jejaring pemasaran dalam pemberdayaan masyarakat, 4) penyuluhan pembuatan keripik singkong aneka rasa. Penyuluhan berjalan lancar dan efektif terjadi peningkatan pemahaman terhadap materi penyuluhan secara siknifikan. Kegiatan pelatihan pembuatan keripik singkong berjalan dengan lancar dan ada keyakinan pada diri ibu-ibu bisa memproduksi secara mandiri. Dalam kegiatan pembukaan jejaring pemasaran masih relatif terbatas karena terkait kondisi topografi wilayah Dusun Sriten yang terjal dan jauh dari akses jalan raya dan keterbatasan kepemilikan kendaraan bermotor. Sampai saat ini baru ada 7 tempat yang bersedia dititipi produk Keripik Singkong Aneka Rasa di wilayah Dusun, Desa dan Kecamatan Nglipar.

\section{Ucapan Terima Kasih}

1. Kepada Pimpinan universitas yang telah mengeluarkan kebijakan terkait adanya pendanaan Program KKN PPM di Universitas Muhammadiyah Yogyakarta.

2. Kepada Kepala LP3M UMY atas dukungan dana kegiatan abdimas ini

3. Kepada Kepala Dukuh Sriten, Kepala Desa Pilangrejo dan Pengurus Kelompok Wanita Tani Dusun Sriten

\section{Daftar Pustaka}

Badan Pusat Statistik. (2020). Kabupaten Gunungkidul Dalam Angka 2020.

Dinas Pertanian DIY. (2016). Luas Panen, Produksi dan Produktivitas Tanaman Padi dan Palawija Per Sub Round Tahun 2016 di Kabupaten Gunungkidul. Website Dinas Pertanian DIY. http://distan.jogjaprov.go.id/ statistik-tanaman-pangan/

Indardi. (2019). Peningkatan Ekonomi Masyarakat Dengan Perbaikan Nilai Tambah Olahan Singkong Di Semuluh Lor, Gunungkidul. Proseding Seminar Nasional Abdimas 2019, Sinergi dan Strategi Academician, Business dan Goverment (ABG) Dalam Mewujudkan Pemberdayaan Masyarakat Yang Berkemajuan Di Era Industri 4.0. UMY Press.

Karsidi, R. (2007). Pemberdayaan Masyarakat Untuk Usaha Kecil dan Mikro (Pengalaman Empiris di Wilayah Surakarta Jawa Tengah). Jurnal Penyuluhan, 3(2). https://doi.org/10.25015/penyuluhan.v3i2.2161

Noor, M. (2011). Pemberdayaan Masyarakat. In Jurnal Ilmiah CIVIS: Vol. I (Issue 2). 